\title{
Culture characteristics and orthophosphate excretion of a marine oligotrich ciliate, Strombidium sulcatum, fed heat-killed bacteria
}

\author{
K. Allali, J. Dolan*, F. Rassoulzadegan \\ Observatoire des Sciences de l'Univers, Université Paris VI /INSU/ CNRS, URA 716, Station Zoologique, BP 28, \\ F-06230 Villefranche-Sur-Mer, France
}

\begin{abstract}
Ciliate microzooplankton have long been hypothesized as probably being important in nutrient regeneration. However, few estimates of excretion rates exist, especially with regard to phosphorus, identified as the limiting nutrient in many marine and estuarine systems. The utility of using heat-killed prey, which avoids prey uptake of excretory products, to measure excretion in feeding ciliates was examined. The growth characteristics of Strombidium sulcatum fed heat-killed vs live bacteria were investigated and orthophosphate excretion rates were estimated. Organismal and orthophosphate concentrations were monitored over an $8 \mathrm{~d}$ incubation period in triplicate solutions of live bacteria, live bacteria plus ciliates, heat-killed bacteria, and heat-killed bacteria plus ciliates. Ciliate cultures fed heat-killed or live bacteria were indistinguishable in terms of the duration of different growth phases, maximum growth rates, maximum concentrations and average cell dry weights based on volume estimates. Calculated orthophosphate excretion rates of $S$. sulcatum, based on changes in concentrations of orthophosphate in cultures fed heat-killed bacteria, were highest for lag-phase cells, $13 \times 10^{-6} \mu \mathrm{g}$-at. ciliate ${ }^{-1} \mathrm{~h}^{-1}\left(24.6 \mu \mathrm{g} \mathrm{P} \mathrm{mg} \mathrm{m}^{-1}\right.$ dry wt $\left.\mathrm{h}^{-1}\right)$ and decreased to zero for late stationary-phase cells.
\end{abstract}

KEY WORDS: Phosphorus · Microzooplankton · Culture

\section{INTRODUCTION}

Nearly 30 yr ago Johannes $(1964,1965)$ suggested that marine ciliates, even if only a minor fraction of total planktonic biomass, could be responsible for a large portion of nutrient recycling in plankton communities. The suggestion was based on evidence that weight-specific excretion rates increase with diminishing body size, a relationship which is now well established (Caron \& Goldman 1990). Johannes' hypothesis is also supported by findings that, rather than being minor constituents, ciliates are often a major component of marine plankton communities (Beers \& Stewart 1969).

Despite the possible importance of ciliates, very few estimates of excretion rates are available for typical marine forms, i.e. tintinnids and oligotrichs. While nitrogen excretion has been investigated in both tintin-

\footnotetext{
-Addressee for correspondence
}

nids (Verity 1985) and an oligotrich (Ferrier \& Rassoulzadegan 1994), phosphorus excretion has only been estimated in terms of turnover time for a freshwater mixotrophic oligotrich, the chloroplast-retaining Strombidium viride (Taylor \& Lean 1981). To our knowledge, data on phosphorus excretion rates for marine ciliates are limited to a single study of a scuticociliate (Berman et al. 1987); there are no phosphorus excretion estimates for marine oligotrichs, generally the dominant group of planktonic ciliates in marine systems.

The lack of data on phosphorus excretion may be partly due to a lack of interest because nitrogen rather than phosphorus is commonly thought to limit primary production in marine systems (Hecky \& Kilham 1988). However, some oceanic systems such as the Mediterranean and the tropical Atlantic may be phosphoruslimited (Berland et al. 1980, Krom et al. 1991, Raimbault \& Pujo-Pay 1993). Recent studies of coastal systems have concluded that phosphorus can be limit- 
ing, depending on the season, for phytoplankton or bacteria in systems as diverse as the Chesapeake (Fisher et al. 1992) and Florida Bays, USA (Fourqurean et al. 1993), Norwegian fjords (Sakshaug \& Olsen 1986, Thingstad et al. 1993), the Baltic Sea (Lignell et al. 1992, Zweifel et al. 1993) and the NW Mediterranean (Zweifel et al. 1993). Another possible explanation for the paucity of data may be the difficulties involved with measuring ciliate excretion rates.

Estimates based on excretion of isotopes involve long incubation times with labeled food to insure equilibrium of all cellular $P$ pools followed by removal of ciliates from their prey (Taylor \& Lean 1981, Taylor 1986), generally, a labor-intensive protocol. Simply following changes in concentration of excretion products in batch cultures neglects absorption of predator excretion by prey organisms. This latter problem has been successfully circumvented in studies using heatkilled prey; the use of inactivated prey allows accumuiation of excretion products (Caron et al. 1990, Ferrier \& Rassoulzadegan 1994). The use of heat-killed prey has become an increasingly popular means of investigating protistan feeding (González et al. 1993, Landry 1994). While growth of ciliates fed heat-killed prey has been recorded (Sherr et al. 1987, Ferrier \& Rassoulzadegan 1994), to our knowledge the culture characteristics of ciliates fed heat-killed prey have not been compared to cultures fed live prey.

Culture characteristics of protists, in terms of cell sizes and growth rates, can vary with the quality of prey (Goldman \& Caron 1985). There is evidence that marine ciliates discriminate against heat-killed prey (Stoecker 1988, Putt 1991). Using heat to kill bacteria does not appear to change the composition of bacteria as regards carbon, nitrogen and phosphorus contents (Caron et al. 1990, Ferrier \& Rassoulzadegan 1994) but it is not unreasonable to assume that many macromolecules and vitamins are altered. In addition, prey motility is clearly altered and might influence ingestion rates and perhaps growth efficiencies in an unpredictable manner. A previous study of ammonium excretion in the oligotrich Strombidium sulcatum fed heat-killed bacteria showed relatively low cell yields with heat-killed bacteria (Ferrier \& Rassoulzadegan 1994). Hence, we were interested in comparing cultures fed live and heat-killed prey in a detailed manner to establish the validity of using heat-killed prey as a food source for ciliate microzooplankton and making estimates of orthophosphate excretion, generally thought to account for most phosphorus excretion in marine protists (Caron \& Goldman 1990).

Here we report the results of an experiment in which we examined the growth of Strombidium sulcatum fed heat-killed and live bacteria. Orthophosphate and organismal concentrations were monitored over an $8 \mathrm{~d}$ incubation period in solutions of live bacteria, live bacteria plus ciliates, heat-killed bacteria, and heat-killed bacteria plus ciliates. Ciliate cultures were compared in terms of the duration of different growth phases. maximum growth rates, maximum concentrations and average cellular dry weights based on volume estimates. We calculated orthophosphate excretion rates of $S$. sulcatum based on changes in concentrations of orthophosphate in cultures fed heat-killed bacteria.

\section{METHODS AND MATERIALS}

Cultures. Inocula for cultures of bacteria were prepared by filtering Villefranche Bay (NW Mediterranean, France) water twice through $0.4 \mu \mathrm{m}$ Nuclepore filters. Double filtration greatly reduces microflagellate concentrations. A small volume of this filtrate, 2 or 3 drops, was used to inoculate 11 volumes of $0.2 \mu \mathrm{m}$ filtered seawater which had been autoclaved after adding 4 wheat grains and $0.1 \mathrm{~g}$ of yeast extract (Difco). Bacterial cultures were incubated at $18^{\circ} \mathrm{C}$ in darkness until cell concentrations were approximately $5 \times 10^{7}$ cells $\mathrm{ml}^{-1}(7 \mathrm{~d})$. Cultures, which were predominantly large rods, were periodically checked for microflagellate contamination.

Stock cultures of Strombidium sulcatum were maintained on bacterized wheat-grain media as previously described (Rivier et al. 1985). For experiments, a ciliate culture was pre-grown on heat-killed bacteria. Ciliates from a stock culture were individually brought through 10 washes of $0.2 \mu \mathrm{m}$ filtered seawater and inoculated into a solution of heat-killed bacteria $\left(1 \times 10^{7}\right.$ bacteria $\mathrm{ml}^{-1}$ ) prepared following the protocol outlined below. The ciliate culture was incubated for $7 \mathrm{~d}$ at $18^{\circ} \mathrm{C}$ in darkness.

Experimental protocol. Bacterial cultures were filtered through $5 \mu \mathrm{m}$ Nuclepore filters to remove aggregates and detrital material and then pooled in an autoclaved container to yield a single $10 \mathrm{l}$ culture. Aliquots, $750 \mathrm{ml}$ volumes, were then dispensed into twelve $1 \mathrm{l}$ containers. Containers of bacterial cultures were assigned one of 4 treatments: (1) no manipulation, (2) addition of ciliates, (3) heat-killing, (4) heatkilling followed by addition of ciliates. Thus, there were 3 replicates for each treatment. Bacterial cultures were heat-killed by placing containers in a $60^{\circ} \mathrm{C}$ water bath for $2 h_{\text {; }}$ ciliate additions represented inoculations from the Strombidium sulcatum culture grown on heat-killed bacteria added to give a final ciliate concentration of $10 \mathrm{ml}^{-1}$. The containers were incubated in darkness at $18^{\circ} \mathrm{C}$. Samples for determinations of orthophosphate and organismal concentrations were removed, after gentle mixing, at time zero and every $24 \mathrm{~h}$ for $8 \mathrm{~d}$. 
Sample processing. Orthophosphate concentrations were determined on unfixed samples using a Technicon AutoAnalyzer (model II). Aliquots removed for bacterial enumerations were preserved with formaldehyde and processed following the DAPI protocol of Porter \& Feig (1980). Samples for ciliate data were preserved with Lugol's solution and $10 \mathrm{ml}$ (Days 1, 2 \& 3) or $2 \mathrm{ml}$ (Days 4 to 8 ) subsamples settled and examined using an inverted microscope. Entire surfaces of the sedimentation chambers were scanned for estimates of ciliate concentrations. Ciliate cell volume estimates were made based on measurements of 30 individuals for samples from Day 4 to Day 8, when ciliates were sufficiently abundant. For these estimates, the first 30 similarly oriented cells in a sample were measured and volumes calculated following the protocol of Ohman \& Snyder (1991) for oligotrichs. Cell volumes, corrected for shrinkage due to fixation in $2 \%$ Lugol's - $65 \%$ live volume (Ohman \& Snyder 1991), were converted to dry weights assuming a specific gravity of 1 and a wet-todry weight ratio of 0.2 (Caron \& Goldman 1990).

Rate calculations. Growth rates were calculated assuming exponential growth. For live bacteria, phosphorous absorption rates ( $A b_{\text {bac }}$ in $\mu \mathrm{g}$-at. $\mathrm{P}_{\text {bacterium }}{ }^{-1}$ $\mathrm{h}^{-1}$ ) were calculated using the relationship:

$$
A b_{\text {bac }}=\left(\left[\mathrm{P}_{1}\right]-\left[\mathrm{P}_{2}\right]\right) /\left(C_{\mathrm{avg} \cdot \mathrm{b}}\left(t_{2}-t_{1}\right)\right)
$$

where $\left[P_{1}\right]$ and $\left[P_{2}\right]$ represent $P$ concentrations ( $\mu$ g-at. $\mathrm{ml}^{-1}$ ) at times $t_{1}$ and $t_{2}$ in $\mathrm{h}$, respectively, and $C_{\text {avg-b }}$ (cells $\mathrm{ml}^{-1}$ ) is the average concentration of bacteria during the interval $t_{1}$ to $t_{2}$ calculated using the Heinbokel (1978) equation for an exponentially growing population:

$$
C_{\mathrm{avg}}=\left(C_{2}-C_{1}\right) /\left(\ln C_{2}-\ln C_{1}\right)
$$

where $C_{1}$ and $C_{2}$ are concentrations of cells $\left(\mathrm{ml}^{-1}\right)$ at $t_{1}$ and $t_{2}(\mathrm{~h})$, respectively. Excretion rates for ciliates feeding on heat-killed bacteria ( $E x_{c i l}, \mu g$-at. P ciliate ${ }^{-1} h^{-1}$ ) were determined using the equation:

$$
E X_{C l}=\left(\left[P_{2}\right]-\left[P_{1}\right]\right) /\left(C_{\text {avg-c }}\left(t_{2}-t_{1}\right)\right)
$$

where $C_{a v g-c}$ is the average concentration of ciliates (cells $\mathrm{ml}^{-1}$ ), calculated as in Eq. (2). Ingestion rates (I, bacteria ingested ciliate ${ }^{-1} \mathrm{~h}^{-1}$ ) of Strombidium sulcatum feeding on heat-killed bacteria were estimated as:

$$
I=\left(B_{1}-B_{2}\right) /\left(C_{\text {avg-c }}\left(t_{2}-t_{1}\right)\right)
$$

where $B_{1}$ and $B_{2}$ are bacterial concentrations (cells $\mathrm{ml}^{-1}$ ) at $t_{1}$ and $t_{2}$, respectively, and $C_{\mathrm{avg}-\mathrm{c}}$ is the average concentration of ciliates for the corresponding interval calculated according to Eq. (3).

Data analysis. Analysis of variance (ANOVA) was used to test for differences between average biomasses of ciliates fed heat-killed or live bacteria. Correlation analysis was used to examine the relationships between measured variables (organismal and phosphate concentrations) as well as calculated rates (excretion and ingestion). Unless otherwise noted, means and SD of the 3 replicates are reported.

\section{RESULTS}

There was little difference between cultures of ciliates grown on heat-killed bacteria compared to cells feeding on live bacteria in terms of the duration of different growth phases, maximum growth rates, maximum concentrations or calculated dry weights. Both treatments yielded growth curves showing a lag phase of $2 \mathrm{~d}$ and an exponential phase of $4 \mathrm{~d}$ followed by a stationary phase (Figs. 1A \& 2A). Maximum
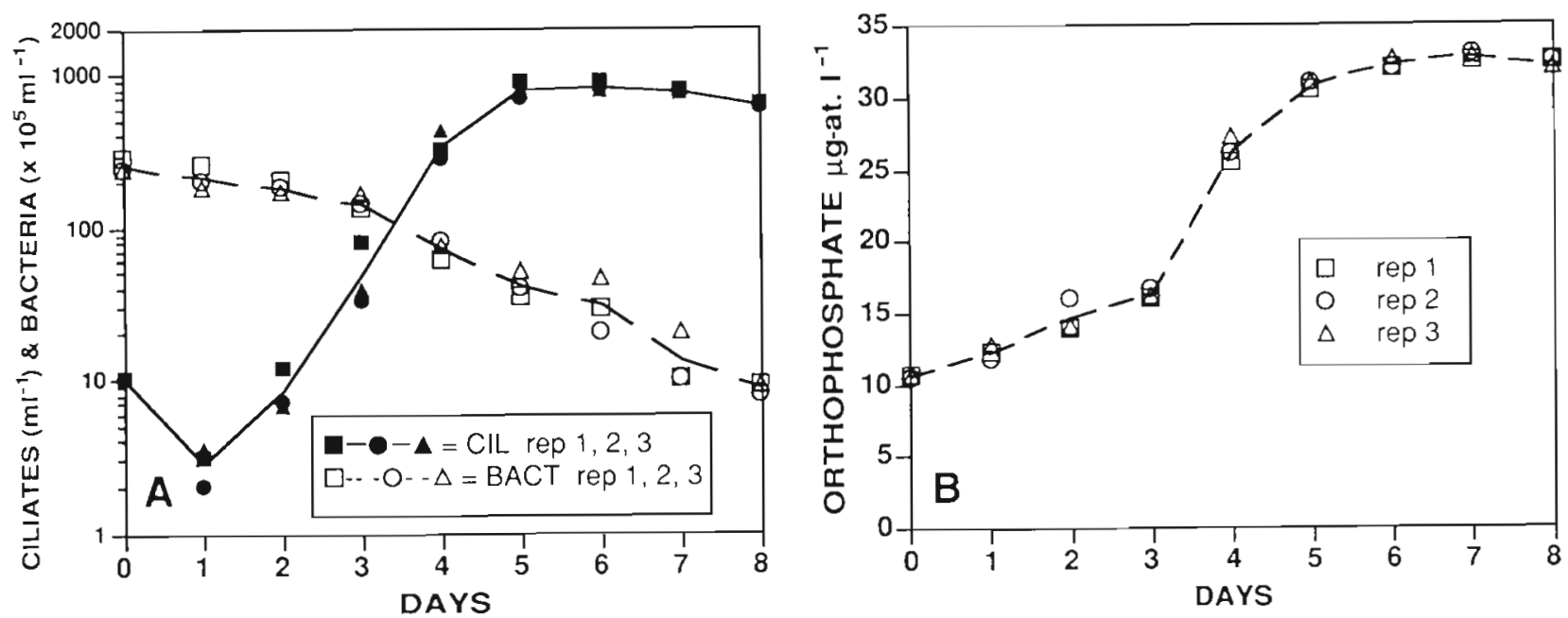

Fig. 1. Strombidium sulcatum. Temporal changes in the concentrations of (A) ciliates and bacteria and (B) orthophosphate in ciliate cultures feeding on heat-killed bacteria. Lines join averages of 3 replicates 

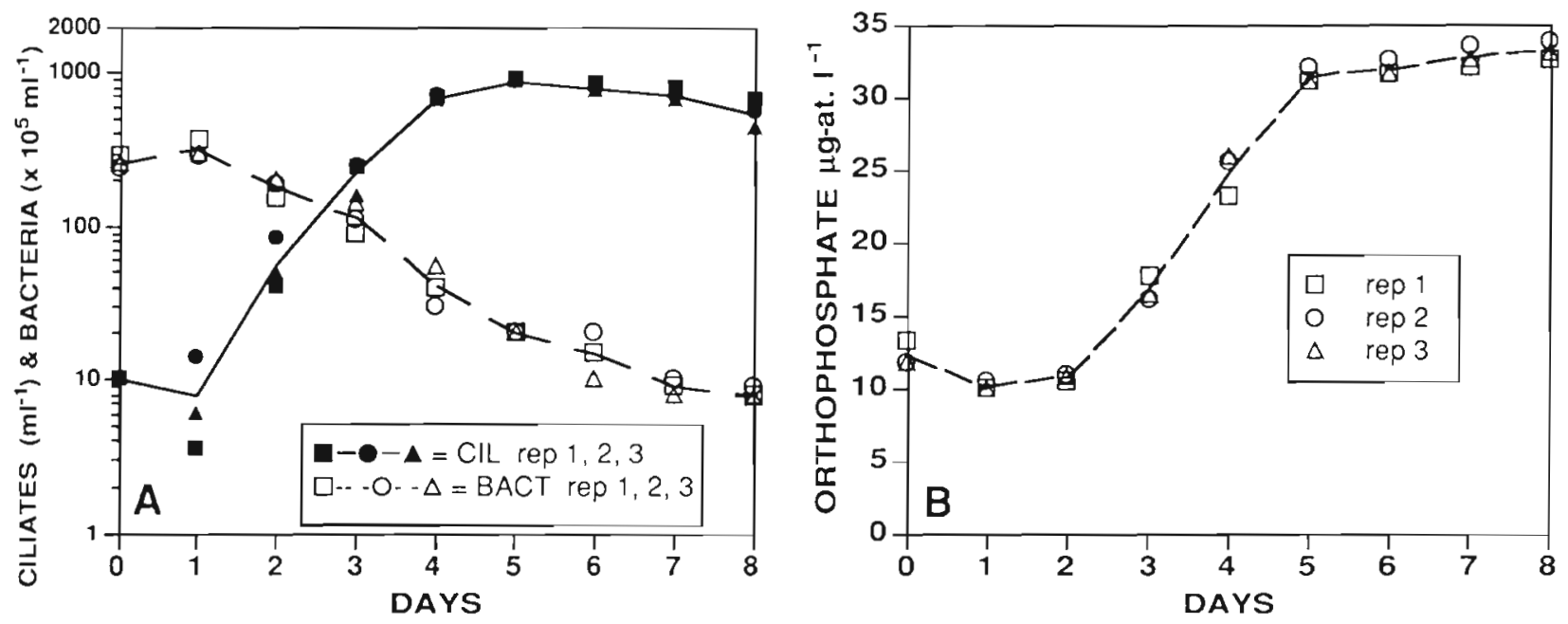

Fig. 2. Strombidium sulcatum. Temporal changes in the concentrations of (A) ciliates and bacteria and (B) orthophosphate in ciliate cultures feeding on live bacteria. Lines join averages of 3 replicates

growth rates were $0.09 \pm 0.01$ and $0.09 \pm 0.02 \mathrm{~h}^{-1}$ for ciliates feeding on heat-killed and live bacteria, respectively. The peak ciliate density recorded for ciliates feeding on heat-killed bacteria was $818 \pm 52.2$ compared to $880 \pm 24.0$ cells $\mathrm{ml}^{-1}$ for cells fed live bacteria. For both treatments the average cell biomass increased from Day 2 to Day 5 and then decreased as prey concentrations declined (Fig. 3). There was no significant difference between the calculated dry weights of ciliates fed heat-killed or live bacteria. Ingestion rates of ciliates feeding on heat-killed bacteria

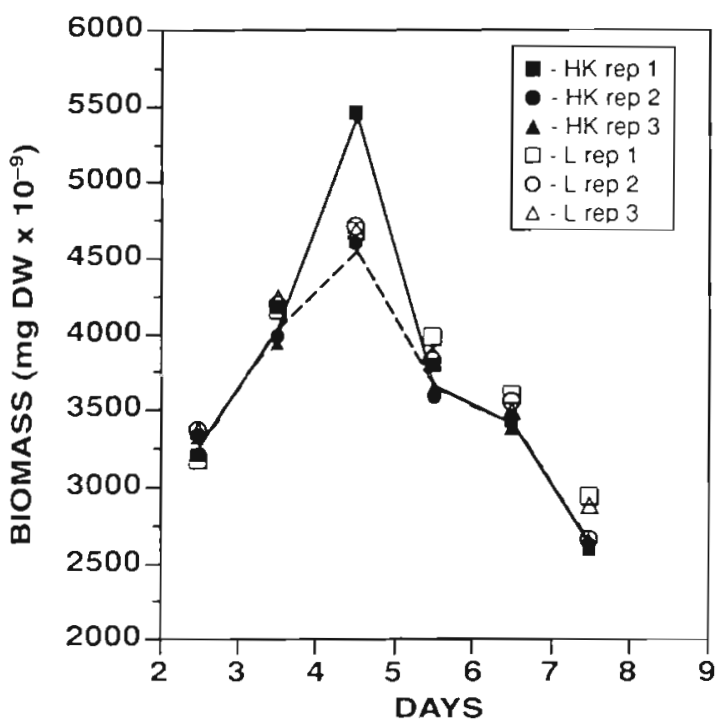

Fig. 3. Strombidium sulcatum. Temporal changes in the average per cell biomass in $\mathrm{mg}$ dry weight (mg DW) of ciliates feeding on heat-killed $(\mathrm{HK})$ and live (L) bacteria. Lines join averages of the 3 replicates declined with time on both a per ciliate and a per unit dry weight basis (Fig. 4).

Phosphorus concentrations increased regularly in solutions of heat-killed bacteria with ciliates from a beginning value of $10.57 \pm 0.137$ to $32.75 \pm 0.23 \mu \mathrm{g}$-at. $\mathrm{P}^{-1}$ at the end of $8 \mathrm{~d}$ (Fig. 1B). Calculated excretion rates were highest at the beginning of the experiment, $13 \pm 12 \times 10^{-6} \mu \mathrm{g}$-at. ciliate ${ }^{-1} \mathrm{~h}^{-1}$ and decreased to zero for late stationary phase cells (Fig. 5). Excretion varied inversely with the concentrations of $\mathrm{P}$ as well as ciliates and were positively related to concentrations of bacteria and calculated ingestion rates (Table 1). Overall, a similar pattern was apparent in solutions of ciliates feeding on live bacteria in terms of increases in $\mathrm{P}$ and

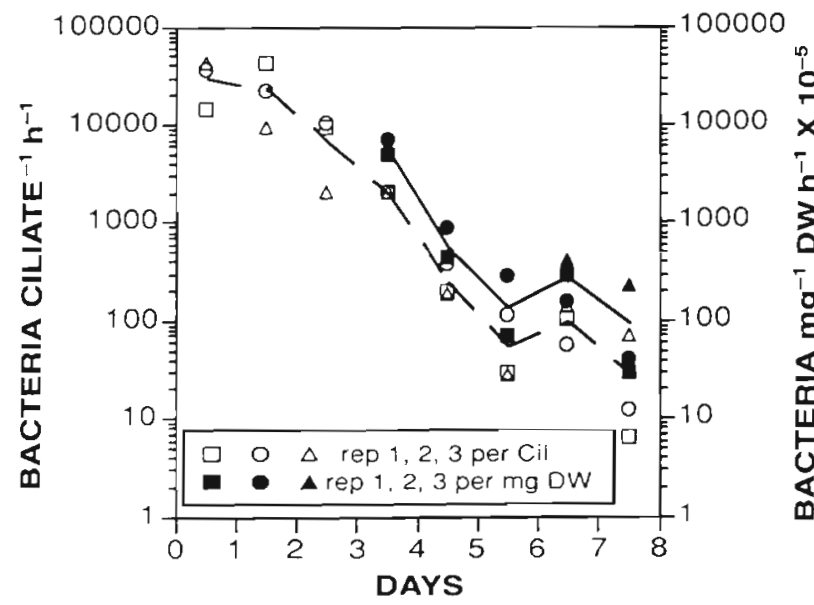

Fig. 4. Strombidium sulcatum. Temporal changes in calculated ingestion rates of ciliates feeding on heat-killed bacteria on a per ciliate (per cil) and per mg dry weight (mg DW) basis. Lines join averages of the 3 replicates 


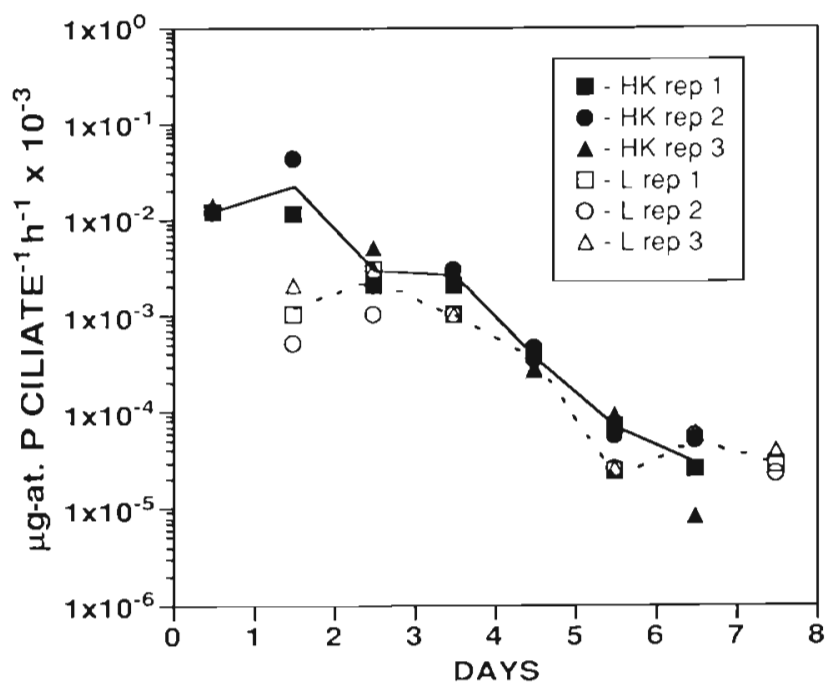

Fig. 5. Strombidium sulcatum. Temporal changes in calculated phosphorus excretion rates based on increases in orthophosphate concentrations in replicate (rep) cultures of ciliates feeding on heat-killed (HK) and live (L) bacteria. Lines join averages of the 3 replicates. Zero and negative values not plotted

Table 1. Results of linear correlation analysis. No data transformation was used and $n=24$ for all correlations

\begin{tabular}{|lccc|}
\hline Treatment & $Y_{1}$ & $Y_{2}$ & r value \\
\hline $\begin{array}{l}\text { Live bacteria } \\
\text { \& no ciliates }\end{array}$ & Bacteria & P conc. & -0.890 \\
$\begin{array}{l}\text { Heat-killed bacteria } \\
\text { \& ciliates }\end{array}$ & $\begin{array}{c}\text { Bacteria } \\
\text { Ingestion }\end{array}$ & $\begin{array}{l}\text { Ingestion } \\
\text { Excretion }\end{array}$ & 0.903 \\
\hline
\end{tabular}

ciliates coupled with decreases in bacterial concentrations (Figs. 2 \& 5). However, in the beginning of the incubations, the solutions of ciliates with live bacteria showed an increase in bacterial densities coupled with a decrease in $\mathrm{P}$ and ciliate concentrations (Fig. 2).

In solutions of heat-killed bacteria without ciliates, bacterial and phosphate concentrations varied little (Fig. 6A). Bacterial numbers at the beginning of the experiment were $2.73 \pm 0.11 \times 10^{7}$ cells $\mathrm{ml}^{-1}$ vs $2.68 \pm$ $0.289 \times 10^{7}$ cells $\mathrm{ml}^{-1}$. Phosphate varied between $12.92 \pm 0.14$ and $12.23 \pm 0.03 \mu \mathrm{g}$-at. $\mathrm{I}^{-1}$. In contrast, in the bottles of live bacteria without ciliates, bacterial concentrations increased and phosphate decreased (Fig. 6B). Bacterial density increased from 2.7 to $9.50 \pm$ $0.026 \times 10^{7}$ cells $\mathrm{ml}^{-1}$ and phosphate declined from an initial value of $11.43 \pm 0.28$ to $5.1 \pm 0.1 \mu \mathrm{g}$-at. $\mathrm{l}^{-1}$. Calculated rates of phosphorus absorption by live bacteria varied from $4.43 \pm 0.13$ to $2.16 \pm 0.62 \times 10^{-12} \mu \mathrm{g}$-at. bacterium $^{-1} \mathrm{~h}^{-1}$ at the beginning and end of the experiment, respectively.
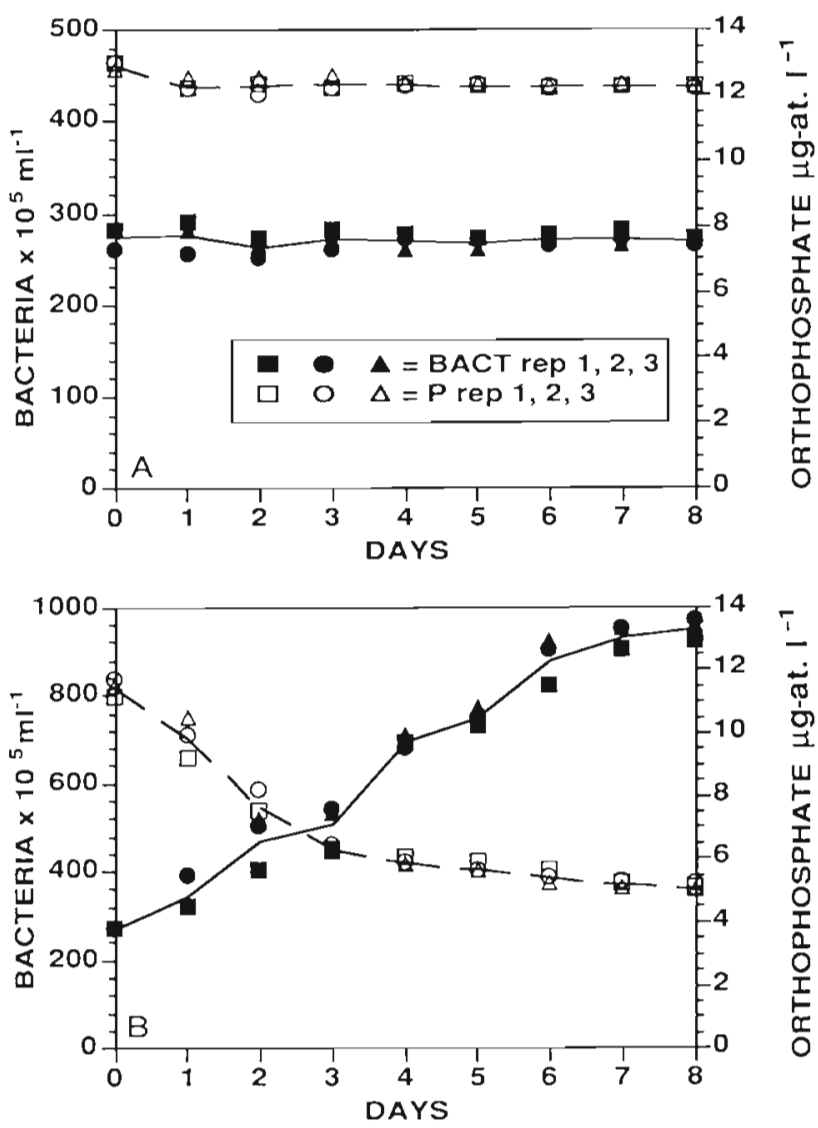

Fig. 6. Strombidium sulcatum. Temporal changes in the concentrations of bacteria and orthophosphate in solutions of (A) heat-killed and (B) live bacteria. Lines join averages of the 3 replicates

\section{DISCUSSION}

We found little difference between Strombidium sulcatum feeding on heat-killed bacteria and live bacteria. Duration of growth phases of the cultures, cell sizes and cell yields were indistinguishable. Hence, using heat to kill bacteria did not appear to affect their nutritional quality for the ciliate. This finding is of some importance. Heat-killed prey (stained or unstained) are often discriminated against, relative to live prey, by microflagellates (Landry et al. 1991, Monger \& Landry 1991) as well as ciliates (Stoecker 1988, Putt 1991), leading some investigators to question the validity of using heat-killed prey as tracers in grazing studies (González et al. 1993, Landry 1994). A previous study, using heat-killed prey and focusing on ammonium excretion of $S$. sulcatum (Ferrier \& Rassoulzadegan 1994), indicated that heat-killed prey supported growth but gave smaller cell yields relative to live bacteria. Our finding of similar culture characteristics with live or heat-killed prey were likely due to the high concentrations of prey employed and the nutrient-replete 
nature of the prey, especially with regard to phosphorus (orthophosphate concentrations of 10 to $11 \mu \mathrm{g}$-at. $\mathrm{P}$ $1^{-1}$ at time 0 ). It is possible that heat-killing of nutrientlimited prey could change nutritional quality.

The similarity between the 2 sets of cultures also extended to final concentrations of orthophosphate (Figs. $1 \mathrm{~B} \& 2 \mathrm{~B}$ ) and estimates of excretion rates for lateexponential and stationary-phase cells (Fig. 5). This may seem surprising given that in the control cultures orthophosphate did not change in solutions of heatkilled bacteria but did diminish in solutions of live bacteria. Rather than indicating that live bacteria in the presence of ciliates did not absorb orthophosphate, this finding is probably due to the relative concentrations and activities of bacteria and ciliates in the cultures. Rough calculations can be made using absorption rates of bacteria from cultures of live bacteria alone. Beyond Day 3 of incubation, bacterial concentrations ranged from $10^{7}$ to $10^{6} \mathrm{ml}^{-1}$ in cultures of ciliates feeding on live bacteria (Fig. 1A). Based on the maximum rates estimated from control cultures $\left(4 \times 10^{-12} \mu \mathrm{g}\right.$-at. bacterium ${ }^{-1} \mathrm{~h}^{-1}$ ), living bacteria absorbed approximately 1 to $0.1 \mu \mathrm{g}$-at. $\mathrm{P}^{-1} \mathrm{~d}^{-1}$, an insignificant amount relative to ciliate excretory activity when ciliate concentrations ranged from 100 to 800 cells $\mathrm{ml}^{-1}$.

Other data on phosphorus excretion rates of ciliates are sparse and difficult to compare directly. Rate estimates have been made only for a marine scuticociliate, Cyclidium sp. (Berman et al. 1987), and a freshwater colpodid, Colpidium sp. (Taylor 1986); both studies examined excretion rates with nutrient-limited prey. For Cyclidium sp., excretion of soluble reactive phosphorus was reported as 0.5 to $15.1 \mu \mathrm{g} \mathrm{P} \mathrm{mg}^{-1}$ dry wt $\mathrm{h}^{-1}$; the comparable values for Strombidium sulcatum are 0 to $24.6 \mu \mathrm{g} \mathrm{P} \mathrm{mg}^{-1}$ dry wt $\mathrm{h}^{-1}$, measured as orthophosphate. For Colpidium sp. phosphorous release was reported as $7.8 \mathrm{pg} \mathrm{P}$ cell ${ }^{-1} \mathrm{~h}^{-1}$ for stationaryphase cells and $12.3 \mathrm{pg} \mathrm{P}$ cell ${ }^{-1} \mathrm{~h}^{-1}$ for exponentialphase cells compared to $0 \mathrm{pg} \mathrm{P}_{\text {cell }} \mathrm{-}^{-1} \mathrm{~h}^{-1}$ and $416 \mathrm{pg} \mathrm{P}$ cell ${ }^{-1} \mathrm{~h}^{-1}$ for stationary and exponential-phase cells, respectively, for $S$ sulcatum. Our maximum rate estimates for $S$. sulcatum are higher likely due to the nutrient-replete nalure of the prey used.

Excretion rates estimated from ciliates feeding on heat-killed bacteria covaried with estimates of ingestion rates and prey concentration (Table 1). While the association of high excretion with high ingestion and low excretion with low ingestion could be expected, a strong correlation between excretion and ingestion rates throughout different growth phases was surprising. We expected to find somewhat lower rates of excretion, relative to ingestion, in rapidly growing cells which synthesize large amounts of membrane and nucleic acids. There is little evidence of such a pattern when excretion divided by ingestion is plotted against

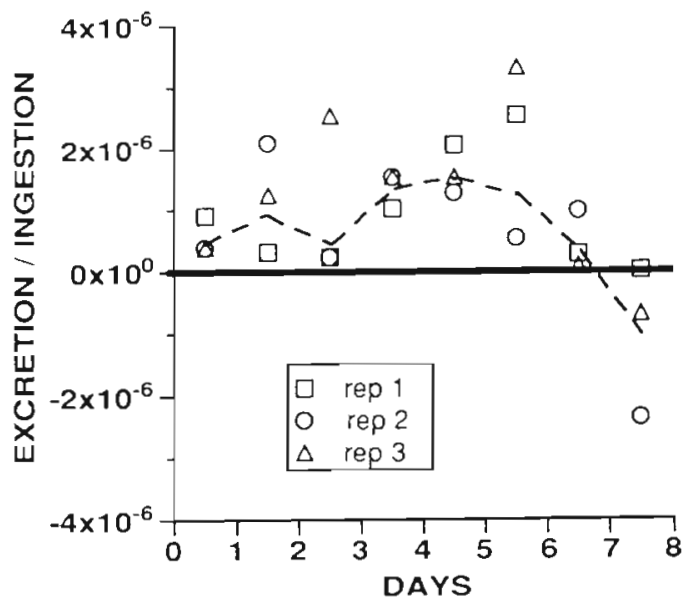

Fig. 7. Strombidium sulcatum. Temporal changes in the ratio of excretion to ingestion of ciliates $[P$ excreted $(\mu \mathrm{g}$-at. P cili$a^{-1} \mathrm{~h}^{-1}$ ) per bacterium ingested] feeding on heat-killed bacteria. Lines join averages of the 3 replicates

time (Fig. 7). Perhaps, with phosphorus-replete prey, excretion could be a simple function of ingestion, regardless of the physiological state of the grazer. This hypothesis should be examined by estimating excretion and ingestion rates in short-term experiments using ciliates in different growth phases or physiological states feeding on a homogeneous prey population. Such experiments have been conducted with Colpidium sp. for excretion but not ingestion rates (Taylor 1986). In our experiment the ciliates could have been feeding on different sub-populations of heat-killed bacteria in lag vs stationary phases complicating calculations of excretion as a function of ingestion.

Heat-killing bacteria does not appear to alter the nutritional value of phosphorus-replete bacteria and allows measurement of excretion rates which are not confounded by prey absorption of excretory products. Future studies will address ciliate excretion when feeding on nutrient-limited prey and address questions of variability with the physiological state of the grazer.

Acknowledgements. The research reported is based on a 'Rapport du Stage' submitted by K.A. to the Université P. \& M. Curie (Paris VI) in partial fulfillment of the requirements for a D.E.A. degree in Biological Oceanography. Financial support was provided by the Commission of the European Communities, MAST II grant MAS 2 - CT93-0063 'Medipelagos' and the Centre National de Recherche Scientifique, URA 716 (France). Comments by anonymous reviewers led to significant improvements in the manuscript.

\section{LITERATURE CITED}

Beers, J. R., Stewart, G. L. (1969). Micro-zooplankton and its abundance relative to the larger zooplankton and other seston components. Mar. Biol. 4: 182-189

Berland, B., Bonin, D. J., Maestrini, S. Y (1980). Azote ou 
phosphore? Considération sur le paradoxe nutritionel de la Méditerranée. Oceanol. Acta 3: 135-1.42

Berman, T., Nawrocki, M., Taylor, G. T., Karl, D. M. (1987). Nutrient flux between bacteria, bactivorous nanoplanktonic protists and algae. Mar. Microb. Fd. Webs 2: 69-82

Caron, D. A., Goldman, J. C. (1990). Protozoan nutrient regeneration. In: Capriulo, G. M. (ed.) Ecology of marine protozoa. Oxford Univ, Press, New York, p. 283-306

Caron, D. A., Porter, K. G., Sanders, R. W. (1990). Carbon, nitrogen, and phosphorus budgets for the mixotrophic phytoflagellate Poterioochromonas malhamensis (Chrysophyceae) during bacterial ingestion. Limnol. Oceanogr 35: $433-442$

Ferrier, C., Rassoulzadegan, F. (1994). N-remineralization in planktonic protozoa. Limnol. Oceanogr. (in press)

Fisher, T. R., Peele, E. R., Ammerman, J. W., Harding, L. W. Jr (1992). Nutrient limitation of phytoplankton in Chesapeake Bay. Mar. Ecol. Prog. Ser. 82: 51-63

Fourqurean, J. W., Jones, R. D., Zieman, J. C. (1993). Processes influencing water column nutrient characteristics and phosphorous limitation of phytoplankton biomass in Florida Bay, FL, USA: inferences from spatial distributions. Estuar. coast. Shelf Sci. 36: 295-314

Goldman, J. C., Caron, D. A. (1985). Experimental studies on an omnivorous microflagellate: implications for grazing and nutrient regeneration in the marine microbial food chain. Deep Sea Res. 32: 899-915

González, J. M., Sherr, E. B., Sherr, B. F. (1993). Differential feeding by marine flagellates on growing versus starving, and on motile versus nonmotile, bacterial prey. Mar. Ecol. Prog. Ser. 102: 257-267

Hecky, R. E., Kilham, P. (1988). Nutrient limitation of phytoplankton in freshwater and marine environments: a review of recent evidence on the effects of enrichment Limnol. Oceanogr. 33: 796-822

Heinbokel, J. F. (1978). Studies on the functional role of tintinnids in the Southern California Bight. 1. Grazing and growth rates in laboratory cultures. Mar. Biol. 47: 177-189

Johannes, R. E. (1964). Phosphorus excretion and body size in marine animals: microzooplankton and nutrient regeneration. Science 146: 923-924

Johannes, R. E. (1965). Influence of marine protozoa on nutrient regeneration. Limnol. Oceanogr. 10: 434-442

Krom, M. D., Kress, N., Brenner, S., Gordon, L. I. (1991). Phosphorus limitation of primary productivity in the eastern Mediterranean. Limnol. Oceanogr. 36: 424-432

Landry, M. R. (1994). Methods and controls for measuring the grazing impact of planktonic protists. Mar. microb. Fd Webs 8: in press

Landry, M. R., Lehner-Fournier, J. M., Sundstrom, J. A., Fagerness, V. L., Selph, K. E. (1991). Discrimination between living and heat-killed prey by a marine zooflagellate, Paraphysomonas vestita (Stokes). J. exp. mar. Biol. Ecol. 146: 139-1.51

Lignell, R., Kaitala, S., Kuosa, H. (1992). Factors controlling phyto- and bacterioplankton in late spring on a salinity gradient in the northern Baltic. Mar Ecol. Prog. Ser. 84: $121-131$

Monger, B. C., Landry, M. R. (1991). Prey-size dependency of grazing by free-living marine flagellates. Mar. Ecol. Prog. Ser. 74: 239-248

Ohman, M. D., Snyder, R. A. (1991). Growth kinetics of omnivorous oligotrich ciliate: Strombidium sp. Limnol. Oceanogr. 36: 922-935

Porter, K., Feig, Y. S. (1980). The use of DAPI for identifying and counting aquatic microflora. Limnol. Oceanogr. 25: $943-948$

Putt, M. (1991). Development and evaluation of tracer particles for use in microzooplankton herbivory studies. Mar. Ecol. Prog. Ser. 77: 27-37

Raimbault, P., Pujo-Pay, M. (1993). Activation d'absortion de nitrate par l'addition de phosphate dans les eaux de l'Atlantique tropical. C. r. Acad. Sci. Paris 316: 740-744

Rivier, A., Brownlee, D. C., Sheldon, R. W., Rassoulzadegan, F. (1985). Growth of microzooplankton: a comparative study of bactivorous zooflagellates and ciliates. Mar microb. Fd Webs 1: 51-60

Sakshaug, E., Olsen, Y (1986). Nutrient status of phytoplankton blooms in Norwegian water and algal strategies for nutrient competition. Can. J. Fish. Aquat. Sci. 43: 389-396

Sherr, B. F., Sherr, E. B., Fallon, R, D. (1987). Use of monodispersed fluorescence labeled bacteria to estimate in situ protozoan bactivory. Appl. environ. Microbiol. 53: 9640-9808

Stoecker, D. K. (1988). Are marine planktonic ciliates suspension-feeders? J. Protozool. 35: 252-255

Taylor, W. D. (1986). The effect of grazing by a ciliated protozoan on phosphorous limitation of heterotrophic bacteria in batch culture. J. Protozool. 33: 47-52

Taylor, W. D., Lean, D. R. S. (1981). Radiotracer experiments on phosphorus uptake and release by limnetic microzooplankton. Can. J. Fish. Aquat. Sci. 38: 1316-1321

Thingstad, T. F., Skjoldal, E. V., Bohne, R. A. (1993). Phosphorous cycling and algal-bacterial competition in Sandsfjord, western Norway. Mar. Ecol. Prog. Ser. 99: 239-259

Verity, P. G. (1985). Grazing, respiration, excretion and growth rates of tintinnids. Limnol. Oceanogr. 30: $1268-1282$

Zweifel, U. L., Norrman, B., Hagström, A. (1993). Consumption of dissolved organic carbon by marine bacteria and demand for inorganic nutrients. Mar. Ecol. Prog. Ser. 101. $23-32$

Manuscript first received: August 17, 1993

Revised version accepted: December 16, 1993 